\title{
Refocusing urban design as an integrative art of place
}

Stephen Marshall MSc(Eng), PgDipUD, PhD

Reader in Urban Morphology and Planning, Bartlett School of Planning,

University College London, London, UK

\begin{abstract}
Urban design finds itself in an existential struggle between its parent disciplines of architecture and planning. This paper advances the case for refocusing on the art of urban design, and the potential for this artistic aspect to play a more definitive role in urban design. The scope of urban design is first briefly outlined and the core role of the art of urban design is suggested. Then, the paper identifies interpretations of urban design as an art, reports critiques of the artistic dimension of urban design, and offers rebuttals of those critiques. Using an analogy with architecture, the paper then suggests an interpretation of urban design as an integrative art and, more specifically, as the articulation of place. The paper advances an agenda for urban design as an integrative art of place, and concludes with reflections on its relation to architecture and planning.
\end{abstract}

\section{Introduction}

Urban design finds itself in an existential struggle between its parent disciplines of architecture and planning. While some might like urban design 'to recover the lost influence of architecture - erstwhile mother of the arts - from its dissolution in an urban field dominated by planners' (Sorkin, 2009: p. 156), contemporary urbanists and planners may desire to 'wrestle urban design away from the bad parenting of architects' (Talen, 2009: pp. 183-185). At the heart of this struggle is the unsettled artistic impulse of urban design.

On the one hand, urban design is traditionally regarded as an art that sets it apart from sciences, from more technical design and from less creative types of policy intervention. On the other, the artistic aspect of urban design has less explicit emphasis today in the face of more pressing technical, societal and planetary prerogatives. Artistic approaches have even been criticised for being naïve, elitist, politically incorrect or a frivolous distraction from more serious concerns of urbanism. While art might have been a formative element of urban design's past, it is not so clear what role it should play in urban design's future.

Urban design itself is in a state of uncertainty as to whether it is a proper discipline. Moreover, urban design has been criticised for its lack of substantial theory and its lack of attention to urban meaning or social content (Cuthbert, 2007) and for its theory being less than wholly scientific (Marshall, 2012). Against this backdrop, the potential role of the art of urban design has often been overlooked or downplayed.

This paper advances the case for refocusing on the art of urban design and the potential for this core aspect of urban design to play a more definitive role in the future of urban design theory and practice. In particular, the paper explores the integrative potential of artistic application and the articulation of place, which could help to supply the substance and coherence that urban design seems currently to lack, over and above any infusion of science or social science.

The paper first briefly outlines the scope of urban design and suggests the core role of the art of urban design. The paper then identifies interpretations of urban design as an art, reports critiques of these interpretations and offers rebuttals of those critiques. Using an analogy with architecture, the paper then suggests an interpretation of urban design as an integrative art and, more specifically, as the articulation of place. The paper then advances an agenda for urban design as an integrative art of place and concludes with reflections on its relation to architecture and planning. There is no space here to address wider issues of the definition and purpose of art as a product or process; the paper generally keeps an open mind on these, although drawing primarily from interpretations of art typically found in urban design literature.

\section{The variable focus of urban design}

Urban design has a multiplicity of definitions (see, for example, the works of Cuthbert (2007), Krieger (2009) and Marshall and Çalişkan (2011)). Indeed, it could be said to lack clear definition (Schurch, 1999: p. 6), but then again its very 'vagueness' could give it unique value (Marshall, 2009a: p. 55). There is ongoing uncertainty over its legitimacy as a field, discipline or profession in its own right (Childs, 2010; Cowan, 2010: p. 88; Lang, 1994; Marshall, 2009a: p. 55; Schurch, 1999: p. 7). Urban design is a sort of 'common ground' (Marshall, 2009a: p. 47), an interdisciplinary or multidisciplinary pursuit (Carmona, 2014; 
Forsyth, 2007: p. 461; Larice and Macdonald, 2007: p. 1; Madanipour, 2006; Moudon, 1992; Schurch, 1999), but also one that 'has yet to coalesce into a viable profession' (Larice and Macdonald, 2007: p. 461). Despite this fissiparous nature, urban design is also recognised for its 'integrative' capacity (Lang, 1994; Larice and Macdonald, 2007: p. 438; Sternberg, 2000). Overall, urban design can be seen as part artistic, part technical and part civic - these three dimensions could be used to frame the broad territory of the field (Figure 1).

Like the other built environment roles, urban design involves a range of technical considerations. Urban design is also routinely assumed to be an art, concerning the composition of spaces and buildings, paying attention to visual aesthetics and urban-scale symbolism (Isaacs, 2000; Moughtin et al., 1995; Owers, 1997: p. 254; Taylor, 1999). Urban design must also be seen as civic or socio-political, because, as long as urban design is dealing with the disposition of space and public realm then it is of public concern (Lang, 1994; Madanipour, 1996). This aspect could be termed 'civic urbanism', connoting an activity that is explicitly socio-political, but whose means are broader than professional design.

Typically, urban design is held to be more than just the artistic part (more than just 'architecture writ large') and to be more than merely technical (more than 'just bollards'; Simmons, 2010), and yet also to be more than just a vaguely defined civic urbanism, by being more physically specific than urban planning. This distinguishes urban design from other kinds of art, design or urban intervention. Figure 2 suggests graphically how urban design could either be considered as the intersection of the artistic, technical and civic spheres, or as

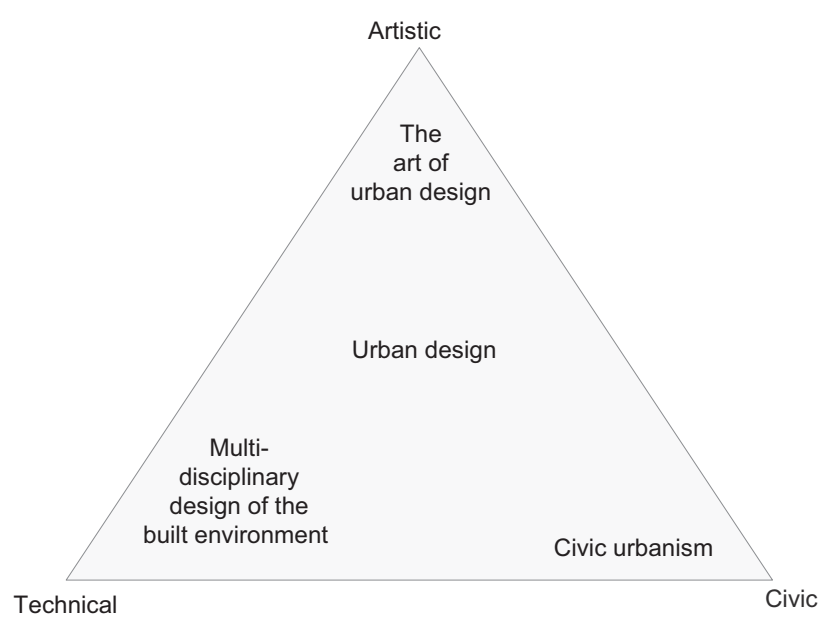

Figure 1. Urban design as a combination of artistic, technical and civic dimensions

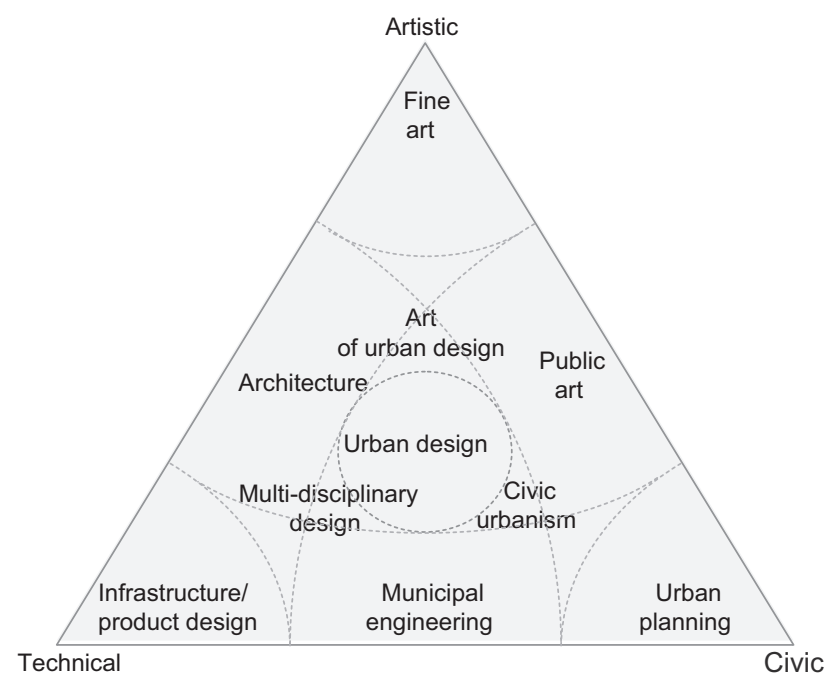

Figure 2. Urban design as part of a wider disciplinary territory; Figure 1 can be interpreted as being nested within Figure 2

an interdisciplinary void between those spheres - depending on how broadly those spheres of influence themselves are defined.

In a broad interpretation, urban design could include any sort of design in an urban area, and so embrace infrastructure design, town design, municipal engineering and architecture (Childs, 2010). It could also be taken to mean any kind of place-making, implying there does not even need to be a professional designer: a 'good' place could have been created by a variety of hands over time, including citizens (Cowan, 1995). This does not deny the essential link with design - it simply repositions all of us as designers. Even more broadly, we could include cases of exemplary urbanism that were not 'designed' as such - 'urban design without urban designers' (Rudofsky, 1965).

Indeed, the compass of urban design could be pushed yet further, beyond the ambit of physical design, to address civil society (Cuthbert, 2007: pp. 178-195) and broader processes of urbanism (Inam, 2011: p. 258), to tackle a broad range of concerns of growing 'urgency and complexity' (Sorkin, 2009: p. 155) from local communities to the regional or even planetary scale (Marshall, 2009a: pp. 55-56; Scott Brown, 2009: p. 84; Sorkin, 2009: p. 175). These are indeed worthy concerns, but these are surely what urban planning is about. That is, if post-war urban design was supposedly invented to plug a gap between architecture and increasingly abstract, regulatory or overly scientific spatial planning (e.g. Sorkin, 2009: p. 156; see also Scully, 1994), then enlarging the scope of urban design to include almost any civic or urban process at any scale is in danger of simply reinventing 'planning' and 
Urban Design and Planning

Volume 168 Issue DP1
Refocusing urban design as an

integrative art of place

Marshall losing the focus that urban design was invented to address (Figure 3).

Alternatively, we might seek to focus on urban design in a narrower sense. In fact, we could specify three ways in which urban design could be so focused.

- First, that it is indeed primarily concerned with shaping the physical urban fabric, as opposed to the disposition of land uses, or concerns of urban agency or municipal politics.

Second, that it is indeed to do with professional design (e.g. preparing a blueprint or some other expression of a solution prior to construction).

Third, that it applies to a specific scale, say from that of the building to that of the urban block or quarter.

This still allows for all three dimensions - artistic, technical and civic - to come into play, but without implying just any kind of urbanism or planning.

The case for a narrower scope is to give conceptual clarity (so the urban part is not too diffuse or incoherent) and a useful division of linguistic labour (so design means design). This does not negate the contribution of other stakeholders who help shape the urban fabric: in fact it acknowledges that the professional art of urban design is not the only way of creating good places - just as not all building design need be architecture.

In this case - that is, unless urban design is to mean any kind of urbanism or design-in-the-built-environment - then there is a

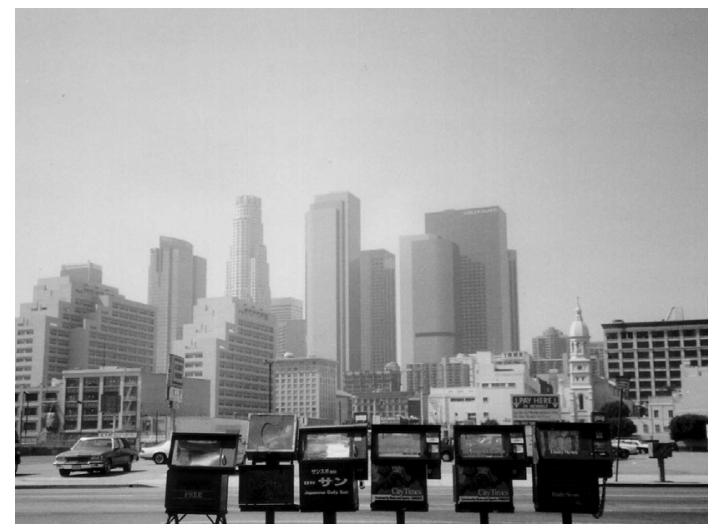

(a)

Figure 3. The broadest interpretation of urban design would include everything from the placement of street furniture to the economic processes shaping the downtown skyline (a), but would also include urbanism created in the absence of 'urban designers' (b) case for the art of urban design to be considered the core or most essential dimension of urban design. The art part is the core part, because it seems difficult to argue that a hypothetical alternative, narrower version of urban design that was only technical or only civic would still be 'urban design' as we know it, if excluding the art of urban design. In turn, this gives rise to another question: what is the role of the art of urban design?

\section{The contested art of urban design}

The idea of a city as a work of art goes back at least to the Renaissance, when 'it was believed that any sculptor or painter, skilled in modelling or drawing visual forms, was able to deal in any formal medium, even on the scale of designing buildings or laying out whole cities' (Benevolo, 1980: p. 473). This general idea carried over into the modern era (Abercrombie, 1933: p. 27; Gibberd, 1962: pp. 16, 20; Korn, 1953: p. 101; Mumford, 1938: p. 480; Rossi, 2003: p. 285). Similarly, town planning (including what we would now call urban design) came to be regarded as an art (Aristotle, 1992; Biddulph, 2012; Cullen, 1971; Gibberd, 1962: p. 14; Hilberseimer, 1944: pp. 167, 170, 191; JohnsonMarshall, 1966; Keeble, 1969: p. 1; Moughtin et al., 1995: p. 1; Mumford, 1938: p. 484; Sitte, 1945; Spreiregen, 1968; Unwin, 1920: pp. 9, 16) and planners or designers could be regarded as artists (Bentley, 2002; Kostof, 1991: pp. 128, 162; Kostof, 1992: p. 232).

Now, we can identify three primary areas of criticism against art-oriented urban design. These concern prerogative (why urban design should be artistic), product (what the art of urban design is) and privilege (who is wielding power for whom).

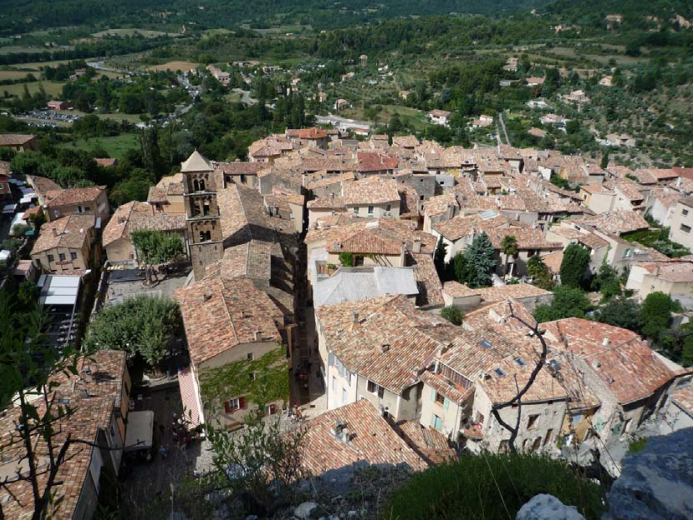

(b) 
- Firstly, art is arguably a low priority compared with more pressing social, economic or environmental prerogatives. There is a danger that urban-design-as-art becomes 'a dilettantish and narcissistic pursuit' (as Jacobs and Appleyard (1987) said of some architecture), divorced from society's needs.

- Secondly, an artistic approach to urban design could be criticised for being a superficial aesthetic treatment, implying unnecessary adornment or irrelevant abstraction, privileging the visual or fetishising the physical. Jane Jacobs classically insisted that a city cannot be a work of art (Jacobs, 1961) (see also Talen and Ellis, 2004: p. 30). Urban design has been criticised for an emphasis on visual appearance (Cuthbert, 2007; Jarvis, 1980: p. 56; Moudon, 1992; Owers, 1997: p. 245) and for a sort of grandiose symbolism, or pandering to abstractions that do nothing for the citizen on the street (Marshall, 2009b: pp. 41-42, 121-122).

- Thirdly, there is the question of who has the right to design the city (Cuthbert, 2010; Mattila, 2002). The urbandesigner-as-artist has been criticised for being 'naïve' (Moudon, 1992), elitist (Jarvis, 1980: p. 54), privileged (Cuthbert, 2007: p. 163) or (implicitly) subsuming the town's needs to the artist's whim (Marshall, 2009b: pp. 38; 121-122).

It is possible to offer rebuttal of these critiques on the same three fronts. Firstly, to defend against the question of 'why', we can use a general 'public art' defence that would suggest art is uplifting and enriching and good for us, so why not artistic urban design? Just because we wish to promote health, safety or energy efficiency in a school or hospital does not mean the school or hospital cannot be aesthetically designed or that there is no place for art in the corridors. If it is acceptable to have a portion of resources from the public purse diverted to artistic purposes, then why not some for the art of urban design?

As for the focus on art as an aesthetic product, just because urban design is an art does not mean it needs to be 'heroic and formal' (Thomas, 2013); it need not mean superficial appearance, grandiose symbolism or futile abstraction. In particular, it need not be a visual art, like painting or sculpture (Bentley, 1999, 2002).

Finally there is the critique of the privileged artist, against which at least four defences can be mounted. Firstly, art is a broad pursuit that may yet have a democratic, collaborative or participatory character (Bentley, 1999; Lang, 1994; Mumford, 1938: p. 484; Raynsford, 2011: p. 49). Art may even be 'generative' (Boden and Edmonds, 2009). Thus we could have a participatory art of urban design, without discarding the aspiration for urban design to be an art. Indeed, compared with more technical aspects such as lighting or drainage design, it is arguably more feasible for the artistic part of urban design to be co-created by diverse lay stakeholders.

Secondly, an art of urban design need not pander to bourgeois tastes or royal clients or serve the interests of global capital any more than any other kind of art. After all, art can include anything from graffiti to guerrilla art, from anti-establishment social realism to state-sponsored 'socialist realism' (Pooler, 2013).

Thirdly, even if art is by its nature elitist in some sense, does this imply we reject all art or any professional skilled activity? Is art too lofty to be considered a priority for the general public? If we can have public art, why not the public art of urban design?

Finally, because urban design is so public and large scale, it has every chance of being the most public artistic asset and shared by the widest population. Any citizen may benefit from urban design's bestowal of an uplifting vista, vital promenade, sheltered space or sense of place. Moreover, an urban design asset cannot be spirited away like any portable commodity (Bentley, 1999: p. 261): a Michelangelo painting could in principle be lost to Italy, but the Campidoglio is not going anywhere.

In any case, there is no need to choose between urban design as social setting or art - a social setting could have artistic treatment. Indeed, arguably the purpose of art is ultimately social - 'Art itself is a social reality' (Fischer, 2010: p. 58; original emphasis) - and need not be seen as separate from 'lived experience' (Dewey, 1958: p. 10).

The question becomes: what could or should the art of urban design look like? Let us assume that it would contain an aesthetic component, including not only the visual but all the senses including kinaesthetic, for which there are existing interpretations available (e.g. Taylor, 1999). But the art of urban design is more than aesthetics. For a fuller appreciation of the potential of the art, we may look to an existing art for inspiration. But, rather than painting or sculpture, let us consider an art closer to urban design.

\section{An integrative art}

Let us imagine that there is no art of architecture. In this scenario, buildings are designed through collaborations between structural engineers, building services engineers and interior designers. Then, imagine proposing an 'art of building design'. One might propose simply applying a decorative adornment to the front of the building. Then the building, once a 'shed', is now a 'decorated shed' (to redeploy a term used by Venturi et al. (1972)). Or, one might propose designing the building as a work 
of three-dimensional sculpture. This would be, to redeploy Venturi et al.'s corresponding term, a 'duck'. Both forms of 'art of building design' could be criticised in our 'no art of architecture' scenario. The decorated shed could be criticised for being a superficial, superfluous adornment to a building that could have been designed by conventional building professionals. Meanwhile the duck could be criticised for being a grandiose, self-indulgent (and in its own way superficial) contrivance, a 'totalitarian embodiment' that puts symbolism and artistic ambition ahead of its broader functionality.

This is roughly the situation faced by an artistic approach to urban design. We are not sure if we need an art of urban design at all, as urban designing could easily be done by a loose collaborative of existing professionals. And critics are sceptical of the value of the would-be art of urban design, if imagined to be the equivalent of decorated 'street pictures' or a giant collective urban 'sculpture'. But clearly there is a third alternative. In the case of building design, it is the art of architecture; that is, an art that articulates something in the form of a building that is neither simply bolting on some other kind of art nor turning into a giant version of another kind of art. Rather, it is its own kind of art (Figure 4).

The implicit benefits of having a dedicated art of architecture suggest benefits for a dedicated art of urban design. In the case of urban design, the art is something that is practised intuitively, but perhaps without full theoretical support. If urban design is to be a substantial art, it needs to find a way of being an art that is, like most architecture, neither superficially decorative nor suffocatingly sculptural.

Architecture has its own body of theory, but also involves recourse to a variety of technical considerations, including knowledge of materials, structural engineering, lighting, ventilation, ergonomics and so on. Those technical areas have their own theories and practitioners. But while knowledge of structures is an essential part of the training of an architect, it does not mean architects themselves becoming structural engineers. Rather, the discipline of architecture involves combining different technical aspects in an integrative way that is not just a matter of functional integration but also takes account of meaning (Yaneva, 2012). In effect, architecture offers a model for being a technically integrative art - the art is not just aesthetic but incorporates the technical dimension (recall Figure 2). Indeed, one could say that architecture transcends the dichotomy between the artistic and the technical.

If architecture is art applied through the medium of buildings, then urban design is art applied through the manipulation of buildings and spaces and other physical features. In architecture, the art makes use of things like structural members as a medium for architectonic expression. The art of urban design uses things like axes, gateways and vistas. Urban design involves further technical considerations - movement and transport, landscape and vegetation - plus a much more definite sense of social and political purpose, of public access and social use of space, of urban vitality and viability. Yet urban designers are not themselves expected to become traffic engineers or retail economists, even if they would ideally have a grasp of the basics of those disciplines. Rather, the urban designer performs an artfully technical integrative role across all these areas.

As an art, urban design has a clear technical and aesthetic remit in its focus on physical form. But what about content and purpose? If urban design is an art, what is that art about?

\section{The art of place}

Place is to architecture, it may be said, as meaning is to language. (Unwin, 1997: p. 15, original emphases)

According to Simon Unwin, the purpose of architecture is to identify place. By extension, it seems useful to assert that the purpose of urban design is to express or create a sense of place. Just as music or photography can convey mood, or clothing can convey 'attitude', architecture and urban design can convey a sense of place. Literature, theatre and film can also create a sense of place, but architecture and urban design do so in a rather direct physical way.

The concept of place immediately brings in connotations of something beyond the merely physical that has so far been lacking in descriptions of urban things and spaces between things. Place conveys something human, yet goes beyond social theory. Place is associated with geographical location, yet is not simply a set of geospatial coordinates. A place is where it is, and what it is, physically - a bend in the river, a slope, a crossroads - but it is equally inextricable with human use, association and identity.

Place becomes the content, the goal, the product of the art of urban design. The point of the physical manipulation and sensory stimulation of urban design is to help create a sense of 'here and there' (Cullen, 1971). The enclosing effect of small alleys off a main street is not simply for the sake of visual or kinaesthetic experience, but to convey something about the 'main-ness' of the main street and the 'side-ness' of the side streets. Urban designers intuitively know this - hence why urban design is sometimes described as the art of place-making.

But place-making must mean more than the physical placement of urban objects at a location or the incorporation of place-signifying materials, styles or artworks. Place has a peculiar character that somehow emerges from the combination of parts - the way this street meets that, which is not only 


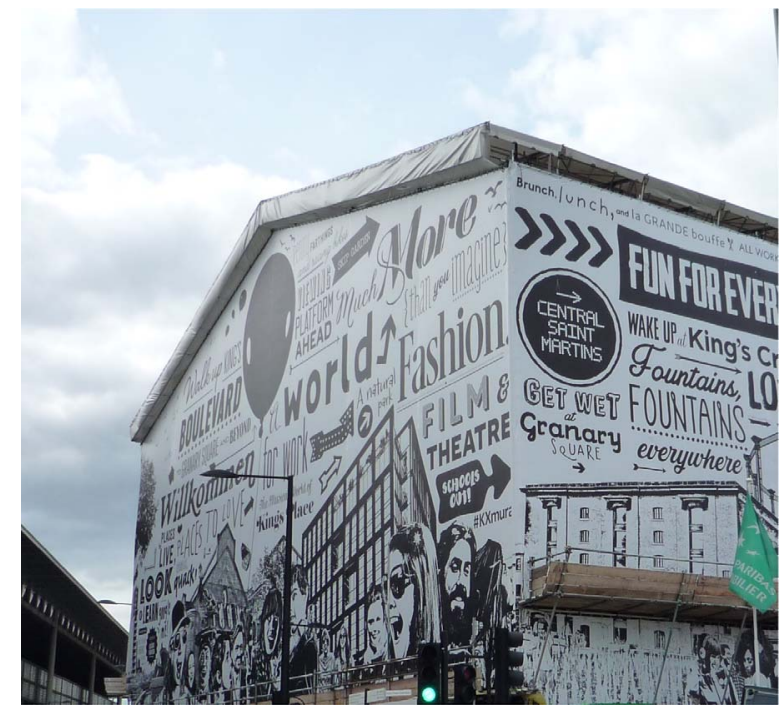

(a)

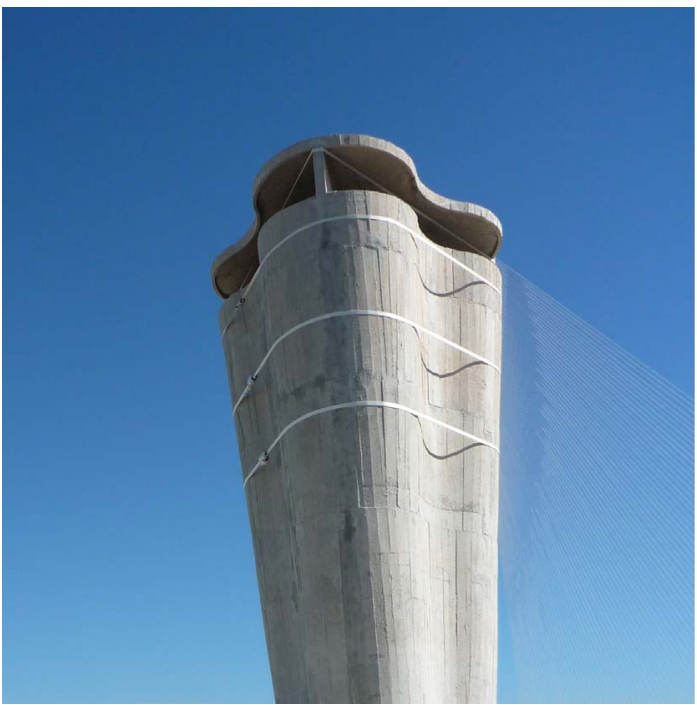

(b)

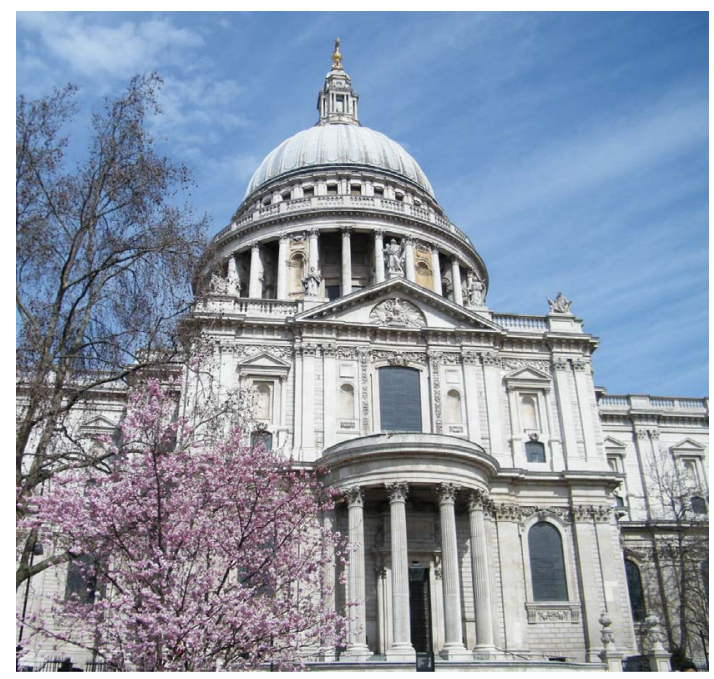

(c)

Figure 4. Alternative approaches to the erstwhile 'art of building

design': (a) 'decorated shed'; (b) 'sculpture'; (c) 'architecture'

about the buildings and geometry, but where the streets go, what the activities and historical associations are, the identity of the location. Place somehow 'inhabits' a physical form or location. We can see how, without this place component, urban fabric design is indeed just a hollow ornament - devoid of content - hence why social theorists criticise purely 'physicalist' approaches in which urban design is merely playing with urban forms signifying nothing.

We can also see that this socially and politically charged nature is precisely why the art of urban design has value - because people value places, they have deep attachments to places; this is the kind of public value that urban design can articulate, supply or release. If the content or product of the art of urban design is seen as place of itself, then that is something subtle and valid that could apply to anywhere in the city, not just to one-off set-pieces. This implies that any and every urban intervention could or should be aware of its place-creating, place-modifying or place-destroying potential.

Seen this way, the significance is that this 'art' of urban design is not just about the urban fabric being 'picturesque'. Nor is it about gross symbolism; it is neither mere visual adornment (a decorated shedscape) nor totalitarian embodiment (an urban sculptural 'duck'). Nor is it the direct equivalent of public art. It is not simply saying something 'about' the place. It is deeper 
than that - it is inextricable with the very essence of the place. As Unwin says

If we think of architecture as designing 'buildings', one designs in one way; if we think of it as identifying places, then one designs in another. (Unwin, 1997: p. 163)

What, then, would the equivalent mean for urban design? There is no space here to fully elaborate urban design as an art of place. However, we can briefly suggest three ways in which a place-making frame of mind would differ from merely 'designing buildings and spaces' or, for that matter, merely incorporating place-signifying content (art, architecture, materials, etc.). Rather, it would involve embodying placesignification in the medium of the urban fabric itself.

- Firstly and most basically, a design could respond directly to the site, expressing something about the physical identity or character of that particular locality. This would not be affecting arbitrary picturesque aesthetics, but would be about relating to existing landmarks or landscape features. For example, a terraced street or square could hug a ravine or river bank, rather than hide it, turn its back on it or obliterate it (Figure 5(a)). This may be considered an artful placement, even if it has no 'artistic' formalism and even if there were no existing urban 'placeness' to relate to.

- Secondly, a design could be in some way referential or symbolic, but not in a generic abstract way that could apply 'anywhere', but rather refer to specific related places. A new block or quarter could artfully respond to the existing urban fabric (Figure 5(b)).

- Thirdly, a place-creating urban design could reflect something real about the use and the social meaning of the place (Figure 5(c)). An example here could be a new public square - such as the proposed civic square in Liverpool's gay quarter (Eastham, 2013) - that can be seen to be more than just an opportunistic use of space or an exercise in formalism or visual expression, but would be a physical articulation of something real and vital - something at once intimate yet public and civic - about the identity and function of the place.

Edinburgh's New Town - which could be considered a classic product of the art of urban design - could claim to be placemaking on all three fronts. Clearly, it responds to the site by its axial alignment along a ridge, affording views to the Old Town to the south and the Firth of Forth to the north: one cannot walk far without being reminded of exactly where one is. Secondly, instead of adopting the gross symbolism of a national flag, it was built as an act of 'ancestral piety', the axis of the central street consciously echoing the ancient high street of the Old Town (McKean, 2011: pp. 44-45). As such, this can be read as a deeper and more satisfying instilling of a sense of place between the old and the new, embedded in the fabric of the locality. Thirdly, the hierarchical street grid can also be interpreted as an expression of the new social order of Enlightenment society (McKean, 2011: pp. 44-45).

In all these cases, urban design is more than just manipulation of physical buildings and spaces; none need involve formally 'artistic' treatment. Urban design is expressing something about the city, locality or community it belongs to, which can be interpreted as an artistic articulation of place

\section{An agenda for the art of urban design}

The argument of this paper in effect suggests an enlargement of the possibility of the art of urban design (Figure 6). To the traditional sense of creating aesthetically satisfying urban ensembles, perhaps most familiarly associated with an artistic treatment (upper vertex), and the artful integrative technical design (lower left) we can add the articulation of place (lower right) associated with the social dimension. In other words, the art itself can be seen to address all three dimensions; in this, urban design is resonant with architecture.

This suggests the possibility of simultaneously focusing the scope of urban design to mean professional physical design at a certain (politically defensible) scale, so that it is not just about any kind of design or urbanism, while expanding the horizons of what art could be, beyond aesthetics to technical integration and articulation of place. That is, so the 'art of urban design' occupies more than just the apex of Figure 1, but urban design per se is more focused than the whole territory of Figure 2. Hence the enlarged art of urban design could be coincident with the overall more focused scope of urban design.

While any design in the built environment might ask itself how far it meets generic social, economic and environmental objectives, the art of urban design would more specifically ask

Is it aesthetically satisfying (not only visually but via other senses)?

Is it an artfully technically integrated product?

Does it contribute meaningfully to expressing or creating place?

To advance the art of urban design, it is suggested that attention is given to

learning more about art

deepening understanding of place

more dedicated education and training

- establishing the limits of (the art of) urban design.

With regards to art, we could first of all do with learning more about the existing artistic practice of urban design - what 
Urban Design and Planning

Volume 168 Issue DP1
Refocusing urban design as an

integrative art of place

Marshall

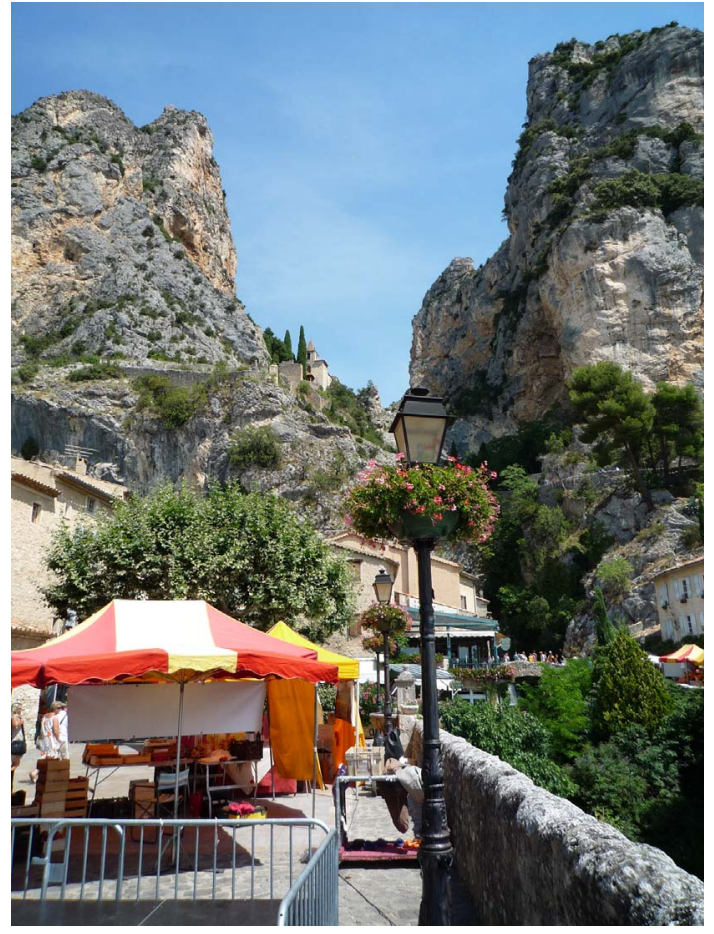

(a)

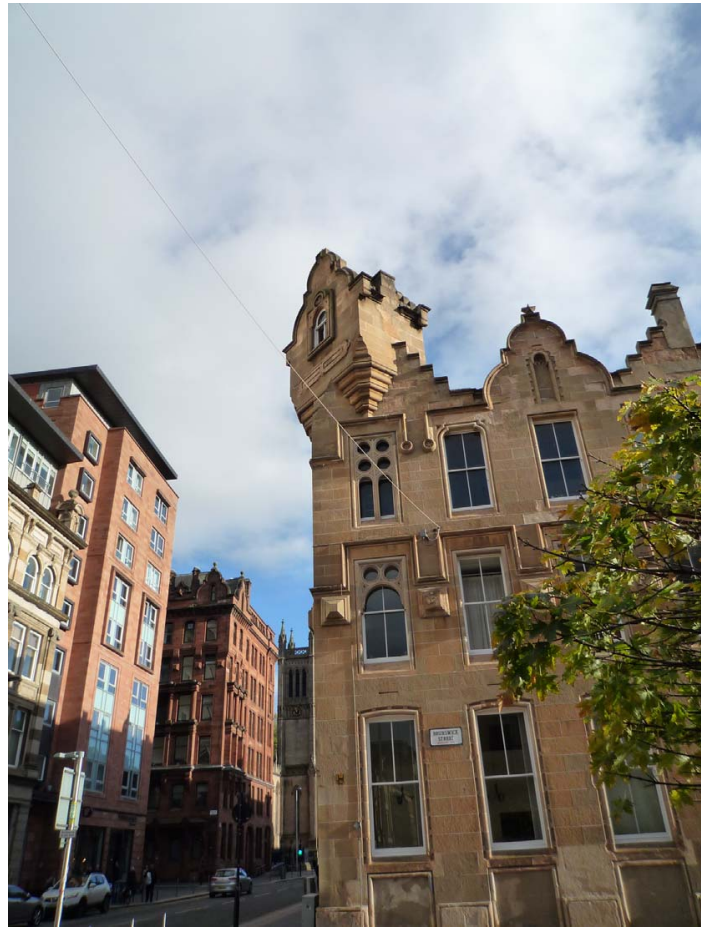

(b)

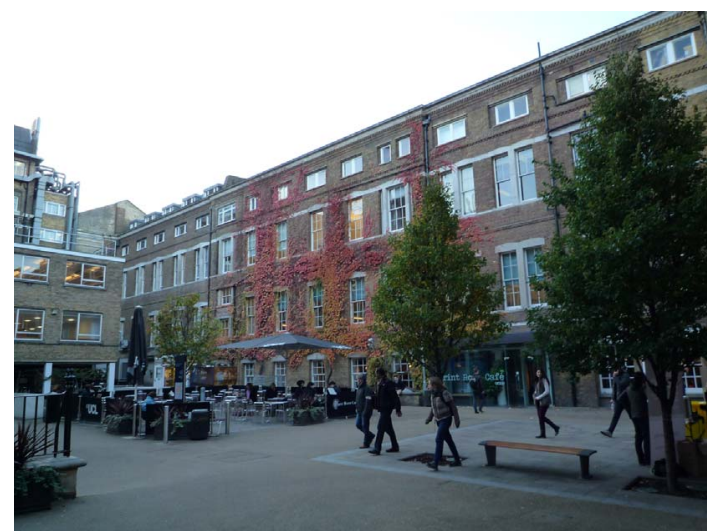

(c)

Figure 5. Urban design as the art of place. (a) A public piazza responds directly to the site - views to a ravine and cliffs - in a Provençal hill town. (b) The retention and insertion of buildings, streets and courtyards in a regenerated quarter respond to the existing urban sense of place (Merchant City, Glasgow). (c) A London university's new 'public square' is not merely an empty formalistic revamp of a formerly utilitarian 'back court', but signifies the heart of a community that already exists urban designers think and do when they design. This aspect is intuitively known by urban designers, but is under-theorised and could benefit from further empirical enquiry (Çalişkan, 2012), particularly regarding the artistic aspect. We could also learn more from the 'arts of place' closest to urban design, such as architecture, landscape architecture, interior design and garden design. We could furthermore learn from a wider range of different ways of 'doing art', including insights from 'alternative' (e.g. participative, generative or guerrilla) forms of art. From these, it should be possible to build artistically informed theory for the art of urban design, as with the theory for the art of architecture.

Secondly, a rich seam of enquiry beckons on the articulation of place. This would include not only learning from existing disparate treatments of place in disciplines such as anthropology, geography, phenomenology and philosophy (Jivén and Larkham, 2003; Najafi and Shariff, 2011), but also new 
Urban Design and Planning

Volume 168 Issue DP1
Refocusing urban design as an

integrative art of place

Marshall

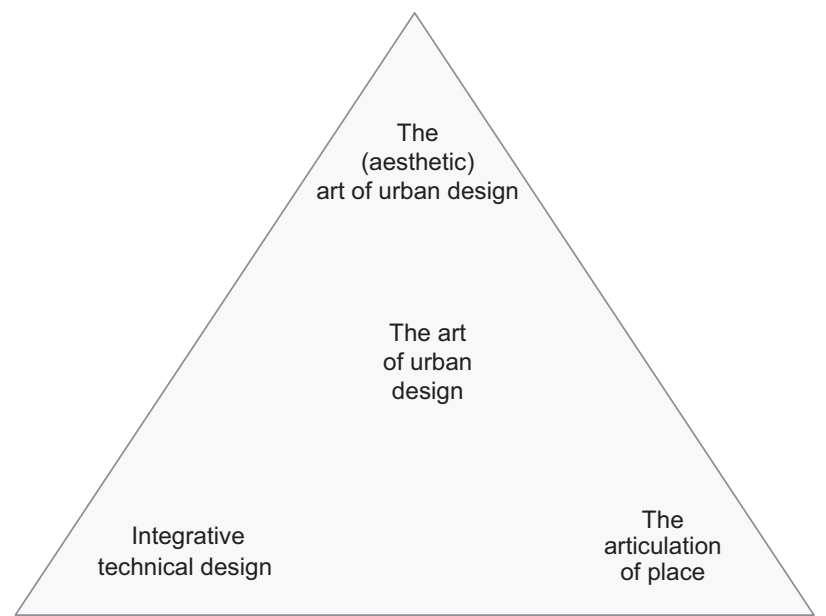

Figure 6. An expanded articulation of the art of urban design; this could be seen as nested somewhere within Figure 1, as Figure 1 is nested within Figure 2

dedicated empirical study, for example linking aesthetics to environmental psychology, neural activity, emotional response and behaviour (e.g. Roe et al., 2013; Roessler, 2012). Such a programme must go beyond understanding places as they are, to address how design can create place - including how to feed public aspirations for place into design.

Thirdly, while urban design habitually distinguishes itself from architecture in scale and scope, urban design education and training could yet benefit from more explicit attention to the 'artistic' (or 'architectural') treatment of urban form. Urban design courses could usefully tackle artistic composition from first principles, from the start directed towards urban design rather than only borrowing principles formed through the lens of building design. Yet, overall, urban design courses must nurture rounded graduates who have both a socio-political understanding of urbanism and place as well as a specific physical design skill-set. (This applies both to Anglophone countries where 'urban design', so labelled, is typically distinguished from architecture and planning and any context (e.g. continental European countries) that may tend to address urban design as urbanism or an extension of architecture.)

Finally, this agenda is not an unqualified endorsement of the art of urban design as the only or best way of creating good urbanism. Not every part of the built environment need be treated to the art of urban design, just as not every building needs an architect. Rather, we should ask the following questions. In what circumstances should we employ this specialised art? What is the legitimate domain of the art of urban design? To what level should the art of urban design be applied or, more broadly, to what level of scale should any holistic design be attempted? This could be subject to further scrutiny to establish a legitimate and practical upper limit of (urban) design.

\section{Conclusion}

This paper argues that urban design is more than just a loose collection of technical design activities - urban design is a technically integrative art, but being artistic need not negate social purpose, and this purpose can be realised partly through the articulation of place.

Attention to the articulation of place can, it is suggested, provide a useful way of reconciling the apparently conflicting prerogatives of art, social science and, indeed, science. The solution to Cuthbert's critique of urban design (Cuthbert, 2007) need not be to abandon the physical concern of urban design nor to attempt to replace urban design theory with second-hand social theory. Neither should a more robustly scientific underpinning of urban design theory (Marshall, 2012) be seen as incompatible with the practical art of urban design; scientific knowledge can underpin any aspect of urban design (technical, civic or aesthetic).

The potential is for the art of urban design to transcend the supposed limitations placed on it by critiques having a limited perspective on art and with nothing constructive to say about design. Perhaps most promisingly, the agenda of articulating place deals with things that urban designers already intuit and wrestle with in the act of design. Rather than requiring ideological re-education in urban design as some sort of 'social production of space', urban designers can approach via the more familiar agenda of 'sense of place'. Place is a handily fluid yet tangible term. It is also suitably accessible - anyone can experience and talk about place. The concept of place forms a useful common ground to rally around, where urban designers may have fruitful exchange with social theorists, geographers and anthropologists on equal terms. That said, this attention to place must entail going beyond the sciences' observation and experience of place, and the social sciences' critiques of place, to tackle matters of art and design for expressing and creating place. In doing so, urban design can offer something constructive that may help to reconcile matters between its squabbling parent disciplines of architecture and planning.

In invoking architecture as a possible role model, this is not to say that urban design should treat design as if a city were a grand-scale building, nor that custody of urban design should be ceded unconditionally to architecture. After all, urban design (as a self-proclaimed activity) has spent much of its existence defining itself as something beyond, and more inclusive than, architecture. Yet the art of urban design implies something much more focused than urban planning or urbanism. It is arguably better to do this artistic part well 
than to attempt to tackle a larger urban agenda with less validity or assurance of success. The perceived 'problem offspring' of architecture and planning is arguably the combination of a limited architectural grasp of urbanism projected on to urban-scale canvas of application. A more useful and humane alternative - which educational programmes should support - would be an urban design that is as open to eclectic influences and alert to civic agendas as planning, but that is as focused as architecture on what it can tangibly deliver as a physically integrative art of place.

\section{REFERENCES}

Abercrombie P (1933) Town and Country Planning. Thornton Butterworth, London, UK.

Aristotle (1992) The Politics (Saunders TJ (ed.)). Penguin, London, UK.

Benevolo L (1980) The Origins of Modern Town Planning. Routledge and Kegan Paul, London, UK.

Bentley I (1999) Urban Transformations: Power, People and Urban Design. Routledge, London, UK.

Bentley I (2002) Urban designers as artists. Urban Design International 7(3-4): 143-152.

Biddulph M (2012) The problem with thinking about or for urban design. Journal of Urban Design 17(1): 1-20.

Boden MA and Edmonds EA (2009) What is generative art? Digital Creativity 20(1-2): 21-46.

Çalişkan O (2012) Design thinking in urbanism: learning from the designers. Urban Design International 17(4): 272-296.

Carmona M (ed.) (2014) Explorations in Urban Design. An Urban Design Research Primer. Ashgate, Farnham, UK.

Childs MC (2010) A spectrum of urban design roles. Journal of Urban Design 15(1): 1-19.

Cowan R (1995) The Cities Design Forgot: A Manifesto. Urban Initiatives, London, UK.

Cowan R (2010) The fine arts of seeing: professions, places, art and, urban design. In What We See. Advancing the Observations of Jane Jacobs (Goldsmith SA and Elizabeth L (eds)). New Village Press, Oakland, CA, USA, pp. 57-67.

Cullen G (1971) The Concise Townscape. Architectural Press, London, UK.

Cuthbert A (2007) Urban design: requiem for an era - review and critique of the last 50 years. Urban Design International 12(4): 177-223.

Cuthbert A (2010) Whose urban design? Review of A. Krieger and W. Saunders (eds) 'Urban Design'. Journal of Urban Design 15(3): 443-448.

Dewey J (1958) Art as Experience. Berkeley Publishing, New York, NY, USA.

Eastham R (2013) A strategic direction for Liverpool's gay village. Proceedings of the Institution of Civil Engineers Urban Design and Planning 166(5): 257-261.

Fischer E (2010) The Necessity of Art, 2010 Reprint. Verso, London, UK.
Forsyth A (2007) Innovation in urban design: does research help? Journal of Urban Design 12(3): 461-473.

Gibberd F (1962) Town Design, 4th edn. Architectural Press, London, UK.

Hilberseimer L (1944) The New City, Principles of Planning. Paul Theobold, Chicago, IL, USA.

Inam A (2011) From dichotomy to dialectic: practising theory in urban design. Journal of Urban Design 16(2): 257-277.

Isaacs R (2000) The urban picturesque: an aesthetic experience of urban pedestrian places. Journal of Urban Design 5(2): 145-180.

Jacobs A and Appleyard D (1987) Towards an urban design manifesto. Journal of the American Planning Association 53(1): 112-120.

Jacobs J (1961) The Death and Life of Great American Cities. Random House, New York, NY, USA.

Jarvis RK (1980) Urban environments as visual art or as social settings? A review. The Town Planning Review 51(1): 50-66.

Jivén G and Larkham PJ (2003) Sense of place, authenticity and character: a commentary. Journal of Urban Design 8(1): 6781.

Johnson-Marshall P (1966) Rebuilding Cities. Edinburgh University Press, Edinburgh, UK.

Keeble L (1969) Principles and Practice of Town Planning, 4th edn. The Estates Gazette, London, UK.

Korn A (1953) History Builds the Town. Lund Humphries, London, UK.

Kostof S (1991) The City Shaped. Urban Patterns and Meanings Through History. Thames and Hudson, London, UK.

Kostof S (1992) The City Assembled: The Elements of Urban Form Throughout History. Thames and Hudson, London, UK.

Krieger A (2009) Where and how does urban design happen? In Urban Design (Krieger A and Saunders WS (eds)). University of Minnesota Press, Minneapolis, MN, USA, pp. 113-130.

Lang J (1994) Urban Design: The American Experience. Van Nostrand Reinhold, New York, NY, USA.

Larice M and Macdonald E (2007) The Urban Design Reader. Routledge, Abingdon, UK.

Madanipour A (1996) The Design of Urban Space. An Inquiry into a Socio-spatial Process. Wiley, Chichester, UK.

Madanipour A (2006) The role and challenges of urban design. Journal of Urban Design 11(2): 173-193.

Marshall R (2009a) The elusiveness of urban design: the perpetual problem of definition and role. In Urban Design (Krieger A and Saunders WS (eds)). University of Minnesota Press, Minneapolis, MN, USA, pp. 38-60.

Marshall S (2009b) Cities Design and Evolution. Routledge, Abingdon, UK.

Marshall S (2012) Science, pseudo-science and urban design. Urban Design International 17(4): 257-271. 
Marshall S and Çalişkan O (2011) A joint framework for urban morphology and design. Built Environment 37(4): 409-426.

Mattila H (2002) Aesthetic justice and urban planning: who ought to have the right to design cities? GeoJournal 58(2-3): 131-138.

McKean C (2011) The controlling urban code of Enlightenment Scotland. In Urban Coding and Planning (Marshall S (ed.)). Routledge, Abingdon, UK, pp. 33-58.

Moudon AV (1992) A catholic approach to organizing what urban designers should know. Journal of Planning Literature 6(4): 331-349.

Moughtin C, Oc T and Tiesdell S (1995) Urban Design: Ornament and Decoration. Butterworth Architecture, Oxford, UK.

Mumford L (1938) The Culture of Cities. Harcourt, Brace and World, New York, NY, USA.

Najafi M and Shariff MKBM (2011) The concept of place and sense of place in architectural studies. International Journal of Human and Social Sciences 6(3): 187-193.

Owers D (1997) Theory and practice in urban design. Built Environment 22(4): 253-257.

Pooler R (2013) The Boundaries of Modern Art. Arena Books, Bury St Edmunds, UK.

Raynsford A (2011) Civic art in an age of cultural relativism: the aesthetic origins of Kevin Lynch's 'Image of the City'. Journal of Urban Design 16(1): 43-65.

Roe J, Aspinall P, Mavros P and Coyne R (2013) Engaging the brain: the impact of natural versus urban scenes using novel EEG methods in an experimental setting. Environmental Sciences 1(2): 93-104.

Roessler KK (2012) Healthy architecture! Can environments evoke emotional responses? Global Journal of Health Science 4(4): 83-89.

Rossi A (2003) The urban artifact as a work of art. In Designing Cities. Critical Readings in Urban Design (Cuthbert AR (ed.)). Blackwell, Oxford, UK, pp. 285-289.

Rudofsky B (1965) Architecture without Architects. Museum of Modern Art, New York, NY, USA.

Schurch TW (1999) Reconsidering urban design: thoughts about its definition and status as a field or profession. Journal of Urban Design 4(1): 5-28.

Scott Brown D (2009) Urban design at fifty. A personal view. In Urban Design (Krieger A and Saunders WS (eds)).

University of Minnesota Press, Minneapolis, MN, USA, pp. 61-87.

Scully V (1994) The architecture of community. In The New Urbanism. Toward an Architecture of Community (Katz P (ed.)). McGraw-Hill, New York, NY, USA, pp. 221-231.

Simmons R (2010) Is urban design just bollards? Proceedings of the Institution of Civil Engineers: Urban Design and Planning 163(2): 49-51.

Sitte C (1945) The Art of Building Cities. City Building According to its Artistic Fundamentals. Reinhold, New York, NY, USA.
Sorkin M (2009) The end(s) of urban design. In Urban Design (Krieger A and Saunders WS (eds)). University of Minnesota Press, Minneapolis, MN, USA.

Spreiregen PD (1968) On the Art of Designing Cities: Selected Essays of Elbert Peets. MIT Press, Cambridge, MA, USA. Sternberg E (2000) An integrative theory of urban design. Journal of the American Planning Association 66(3): 265278.

Talen E (2009) Bad parenting. In Urban Design (Krieger A and Saunders WS (eds)). University of Minnesota Press, Minneapolis, MN, USA, pp. 183-185.

Talen E and Ellis C (2004) Cities as art: exploring the possibility of an aesthetic dimension in planning. Planning Theory and Practice 5(1): 11-32.

Taylor N (1999) The elements of townscape and the art of urban design. Journal of Urban Design 4(2): 195-209.

Thomas L (2013) Art, and not just for art's sake. Urban Design 128(Autumn): 2.

Unwin R (1920) Town Planning in Practice. An Introduction to the Art of Designing Cities and Suburbs, 2nd edn. Bern, London, UK.

Unwin S (1997) Analysing Architecture. Routledge, London, UK.

Venturi R, Scott Brown D and Izenour S (1972) Learning from Las Vegas. MIT Press, Cambridge, MA, USA.

Yaneva A (2012) Mapping Controversies in Architecture. Ashgate, Farnham, UK.

\section{WHAT DO YOU THINK?}

To discuss this paper, please email up to 500 words to the editor at journals@ice.org.uk. Your contribution will be forwarded to the author(s) for a reply and, if considered appropriate by the editorial panel, will be published as discussion in a future issue of the journal.

Proceedings journals rely entirely on contributions sent in by civil engineering professionals, academics and students. Papers should be 2000-5000 words long (briefing papers should be 1000-2000 words long), with adequate illustrations and references. You can submit your paper online via www.icevirtuallibrary.com/content/journals, where you will also find detailed author guidelines. 